\title{
The Expanding Role of Radiosurgery for Brain Metastases
}

\author{
Mark O'Beirn ${ }^{1}$, Helen Benghiat ${ }^{1}$, Sara Meade ${ }^{1}$, Geoff Heyes ${ }^{1}$, Vijay Sawlani ${ }^{2}$, Anthony Kong ${ }^{1}$, \\ Andrew Hartley ${ }^{1}$ and Paul Sanghera ${ }^{1, *}$ \\ 1 Hall-Edwards Radiotherapy Research Group, Queen Elizabeth Hospital Birmingham, Edgbaston, \\ Birmingham B15 2TH, UK; mark.obeirn@nhs.net (M.O.); helen.benghiat@uhb.nhs.uk (H.B.); \\ sara.meade@uhb.nhs.uk (S.M.); geoff.heyes@uhb.nhs.uk (G.H.); anthony.kong@uhb.nhs.uk (A.K.); \\ andrew.hartley@uhb.nhs.uk (A.H.) \\ 2 Neuroradiology, Queen Elizabeth Hospital Birmingham, Edgbaston, Birmingham B15 2TH, UK; \\ vijay.sawlani@uhb.nhs.uk \\ * Correspondence: paul.sanghera@uhb.nhs.uk
}

Received: 23 July 2018; Accepted: 7 August 2018; Published: 14 August 2018

\begin{abstract}
Stereotactic radiosurgery (SRS) has become increasingly important in the management of brain metastases due to improving systemic disease control and rising incidence. Initial trials demonstrated SRS with whole-brain radiotherapy (WBRT) improved local control rates compared with WBRT alone. Concerns with WBRT associated neurocognitive toxicity have contributed to a greater use of SRS alone, including for patients with multiple metastases and following surgical resection. Molecular information, targeted agents, and immunotherapy have also altered the landscape for the management of brain metastases. This review summarises current and emerging data on the role of SRS in the management of brain metastases.
\end{abstract}

Keywords: stereotactic radiosurgery (SRS); stereotactic radiotherapy (SRT); brain metastasis; immunotherapy; whole brain radiotherapy (WBRT)

\section{Background}

Intracranial stereotactic radiosurgery (SRS) was pioneered in the 1950s by the Swedish neurosurgeon Lars Leksell. The technique relies on multiple beams of radiation intersecting at a target precisely located within three dimensions. A single high dose of radiation is delivered with very rapid dose fall off in order to minimise the risk of damage to any adjacent tissue. The Gamma Knife was the first commercial intracranial SRS system and was based on Lars Leksell's initial prototype, utilising fixed cobalt sources and surgical immobilisation of the skull to manage motion [1]. Subsequently the technique was replicated using linear accelerators subject to additional quality assurance and motion management strategies [2]. The Cyberknife is a specialist linear accelerator, mounted on a robot, which is capable of delivering SRS without the need for surgical immobilisation of the skull. Small well-demarcated tumours are the most suitable targets for SRS and brain metastases are now one of the most common indications (See Figure 1). 


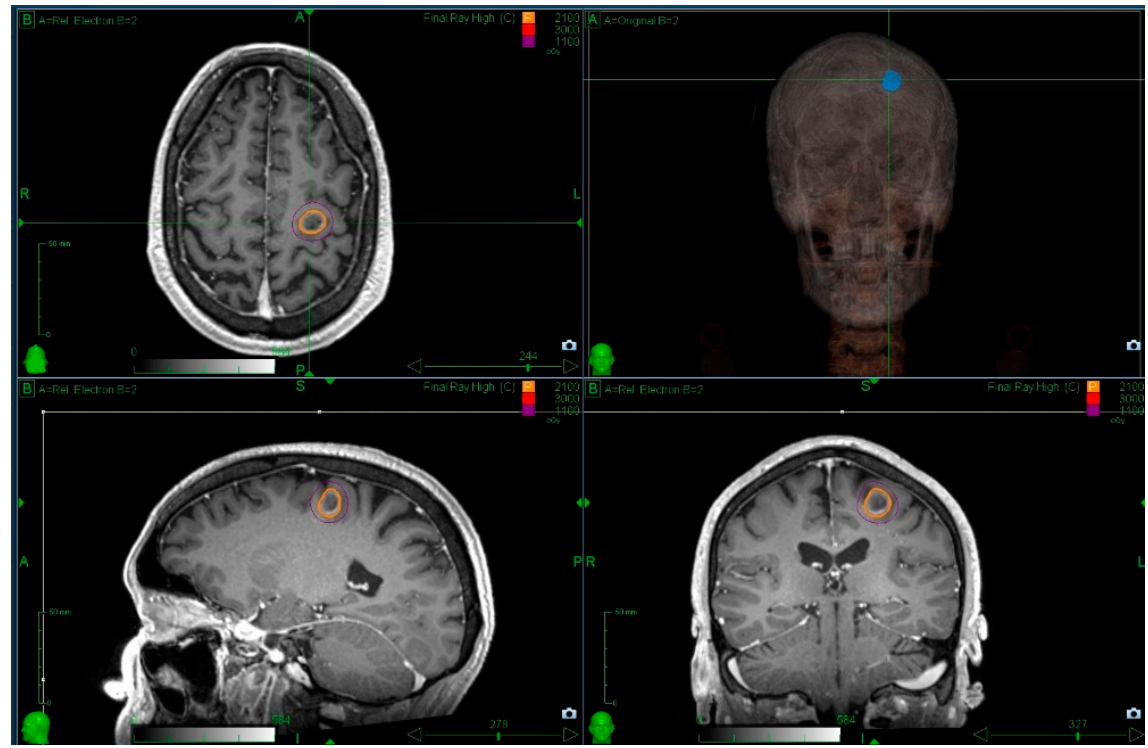

Figure 1. Radiosurgery for patients with a single metastasis and a favourable prognosis is standard practice. The figure illustrates a single metastasis covered with a prescription dose of 21 Gy prescribed to the $70 \%$ isodose line using Cyberknife. Prior informed consent was obtained for use of these images.

Brain metastases represent a significant cause of cancer morbidity, occurring in around $30 \%$ of patients with a malignancy originating outside the central nervous system [3]. The management of intracranial metastatic disease is made complicated by the impermeability of the blood-brain barrier to many chemotherapeutic agents, rendering this region a 'sanctuary site' for malignancies, most commonly breast, lung, melanoma, and renal cell carcinoma [4]. In 1999, a single-centre randomised controlled trial (RCT), in which patients with 2-4 brain metastases were treated with whole-brain radiotherapy (WBRT), alone or in combination with SRS, was stopped early due a significant improvement in the local control of the combination arm. All the patients had a local failure after 1 year within the WBRT group, compared to $8 \%$ following WBRT with SRS [5]. In 2004, the RTOG 9508 randomised trial demonstrated that the addition of SRS to WBRT improved survival for patients with a single metastasis compared with WBRT alone (median survival 6.5 months vs. 4.9 months, $p=0.04)$. Patients in the SRS group were more likely to have a stable Karnofsky Performance Status score at six months compared to WBRT alone (43\% vs. 27\% respectively, $p=0.03$ ) [6]. These early studies helped to establish a role for SRS. As the principle benefit of SRS was durable control, several groups developed tools to help select those patients who were more likely to have a prolonged survival [7-13]. One of the earliest and simplest tools was the recursive partitioning analysis (RPA) derived from patients treated with WBRT within RTOG studies [14]. Patients were assigned to one of three prognostic groups based on performance status, age, presence of extracranial disease, and control of primary disease. Median survivals were 7.1, 4.2, and 2.3 months within RPA groups 1, 2, and 3, respectively. Although patients within group 1 would be candidates for SRS, the range within the middle category was broad. Subsequently, more sophisticated tools such as the diagnosis specific graded prognostic assessment (dsGPA) have been developed, which take into account the primary disease site to help selection [10]. However, an analysis evaluating the utility of six tools found that the benefits with more sophisticated tools were modest [15]. Recently the dsGPAs have been updated for selected primary sites, taking into account molecular information where possible [16,17].

Despite the modest survival benefit limited to a single metastasis within the original RTOG randomised trial [6], ongoing improvements in systemic survival, imaging, and more efficient SRS technology have led to a considerable expansion in practice. Furthermore, the potential for WBRT associated neurotoxicity in long-term survivors has led to a shift in practice [18]. The purpose of this review is to provide an update on the use of SRS for brain metastases within the contemporary era. 


\section{Methodology for Search Selection}

Although not a systematic review, a literature search of Medline, the Cochrane Library, CINAHL, Embase, and Google Scholar was performed using the following terms: "Stereotactic radiosurgery", "Stereotactic radiotherapy", "SRS", "SRT" and "Brain Metastasis", "Immunotherapy", or "resection". The search focused on prospective studies, meta-analyses, systematic reviews, and retrospective studies with greater than 20 cases.

\section{Discussion}

\subsection{Whole Brain Radiotherapy in Combination with Radiosurgery}

WBRT was the historic standard of care prior to the widespread use of SRS [19]. However, the principle concern with WBRT, particularly in patients with a more favourable prognosis, is the negative impact on neurocognitive function (NCF) and quality of life [20]. NCF data is challenging to collect beyond a year, and baseline impairment often occurs in the presence of brain metastases [21-23]. An imaging study with a median follow-up of 6.25 years post-WBRT did show a significant impact on the rate of cerebral atrophy [24], and several clinical studies have reported shorter term outcomes comparing WBRT with observation following SRS.

Aoyama et al. assessed 132 patients randomised to SRS alone versus SRS with WBRT; they reported no differences in overall survival or NCF using a mini mental state examination (MMSE) [25]. However, this study was stopped early due to the sample size required to detect a survival difference, and the MMSE is a poor tool to evaluate post WBRT NCF impairment [26]. Chang et al. used a validated NCF tool and randomised 58 patients with 1-3 metastases between SRS alone and SRS with WBRT. The study was stopped early based on an interim analysis of 31 patients. Patients assigned to the WBRT group were more likely to have deterioration in the primary endpoint of total recall at 4 months, as measured by the 'Hopkins Verbal Learning Test-Revised' [27]. The mean posterior probability of decline was $52 \%$ in the SRS plus WBRT group versus $24 \%$ in the SRS alone group. A larger multi-institutional study randomised 213 patients between SRS alone and SRS plus WBRT with a primary endpoint of cognitive deterioration using a validated battery of tests. There was also significantly greater deterioration at 3 months using SRS with WBRT compared to SRS alone, $91.7 \%$ versus $63.5 \%$ (difference, $-28.2 \%, 95 \%$ confidence interval $(\mathrm{CI}),-41.9 \%$ to $-14.2 \%, p<0.001$ ). The quality of life also improved with SRS alone at 3 months $(p=0.001)$. The median follow-up was only 7.2 months, however, within a small subset of longer term survivors selected cognitive benefits were seen at 12 months with cognitive deterioration in executive function occurring more frequently after SRS plus WBRT compared with SRS alone, (42.9\% vs. $0.0 \%$, respectively; difference, $42.9 \%$, $95 \%$ CI, $7.8 \%-77.9 \%, p=0.05$ ) [28]. A multi-centre European study randomised 359 patients with 1-3 metastases undergoing SRS or surgery between observation and adjuvant WBRT. There was no difference in the primary endpoint of duration of patients' functional independence ( $p=0.89)$ [29]. A secondary endpoint was quality of life and patients had significantly higher global health related quality of life mean scores at 9 months with observation alone [30].

These aforementioned RCTs have consistently shown that WBRT improves intracranial control of disease, predominantly through a reduction of distant brain relapse, without a survival advantage [25,27-29]. A meta-analysis of individual patient data within the 3 of these RCTs evaluated 364 out of 389 pooled patients. Subset analyses were performed, and patients with a single metastasis had a significantly lower risk of distant brain failure than patients with $2-4$ metastases $(\mathrm{HR}=0.63$, $C I=0.56-1.14)$. Age was an important factor as a continuous variable, and there was no difference in distant brain relapse between observation and WBRT in patients aged $\leq 50$ years. There was also a significant survival advantage for patients aged $\leq 50$ years with SRS alone and hazard ratios for patients 35, 40, 45, and 50 years of age were 0.46 (95\% CI, 0.24-0.90), 0.52 (95\% CI, 0.29-0.92), $0.58(95 \%$ CI, 0.35-0.95), and 0.64 (95\% CI, 0.42-0.99), respectively [31]. The only data to support a survival advantage from the addition of WBRT to SRS comes from a post-hoc analysis of lung cancer 
patients treated with SRS alone or SRS plus WBRT within the JROSG 99-1 study [32]. Patients with a favourable prognosis of lung cancer (dsGPA 2.4-4.0) had a survival advantage, with a median survival of 16.7 months (95\% CI, 7.5-72.9) versus 10.6 months (95\% CI, 7.7-15.5) ( $p=0.04)$. As with any observation strategy, the ability to detect progression and offer prompt salvage therapy is important to reduce the chance of neurological morbidity and death. However, most now regard the new standard for patients with 1-3 brain metastases as SRS alone [18].

\subsection{Radiosurgery Following Surgical Resection}

Surgical excision is preferred for brain metastases where histological confirmation is required. Alternatively, the removal of large symptomatic masses can improve quality of life and permit more prompt withdrawal of steroids. For these reasons, a direct comparison of SRS to surgical resection has proven difficult with one attempted prospective study failing to accrue and closing early without providing an answer [33].

Failure in the surgical bed occurs in approximately $60 \%$ of cases at 2 years following resection alone and this is significantly reduced by adjuvant WBRT [29]. However, due to WBRT associated neurotoxicity, there has been increasing interest in conformal therapy to the surgical cavity including SRS. In a single centre RCT, patients who had a complete resection of 1-3 brain metastases were randomly assigned to SRS to the cavity or observation. The 12-month freedom from local recurrence was $72 \%$ (95\% CI, 60-87) in the SRS group compared with $43 \%$ (95\% CI, 31-59) in the observation group, with no adverse events or treatment-related deaths [34]. The median time to recurrence was 7.6 months in the observation group (95\% CI, 5.3 months to NR) and not reached in the SRS group (95\% CI, 15.6 months to NR). There was no difference in median overall survival (OS). Metastasis size was inversely correlated with better local control (LC) and tumours below $2.5 \mathrm{~cm}$ had a $90 \%$ freedom from local recurrence. In a multicentre RCT, patients with a single resected brain metastasis were assigned to cavity SRS or WBRT with the co-primary endpoints of cognitive-deterioration-free survival and OS. Patients with a cavity of $<5 \mathrm{~cm}$ were included, and the dose was determined by the surgical cavity volume. The target volume consisted of the surgical cavity plus a $2 \mathrm{~mm}$ margin. The cognitive deterioration-free survival was slightly longer in patients assigned to SRS compared with those assigned to WBRT: 3.7 months versus 3 months respectively. Cognitive deterioration at 6 months was more frequent in patients who received WBRT than with those who received SRS ( $85 \%$ versus $52 \%$ respectively. Difference $-33.6 \%$ (95\% CI, -45.3 to -21.8$), p<0.00031)$. There was no difference in the median OS between the groups, however the SRS group had inferior 6 month LC compared to WBRT: $80.4 \%$ versus $87.1 \%$ respectively $(p=0.00068) .12$ month LC rates were also inferior (61\% versus $81 \%)$ and there was a shorter time to intracranial tumour progression: median 6.4 months versus 27.5 months in the WBRT group $(p<0.0001)$ [35]. In a small Polish study, patients undergoing resection of a single brain metastasis were randomised to WBRT or SRS or hypofractionated stereotactic radiotherapy (hfSRT). A dose of 15-18 Gy was used, or 25 Gy in 5 fractions for cavities larger than $5 \mathrm{~cm}$ or irregular in shape. The study was underpowered to make conclusions, although the surgical bed relapse was similar in both arms, and distant brain relapse was reduced with WBRT. Unlike other trials, the two-year OS rates appeared better in the early WBRT group than in the SRS group: $37 \%$ versus $10 \%, p=0.015$ [36].

Although the LC with cavity SRS may be lower than with WBRT, the improvement over observation with minimal associated morbidity has led many to adopt this as standard practice. The suitability of SRS for treating targets of a larger size and irregular shape is challenging, due to the interpretation of postoperative changes. The approach requires cooperation with a neuro-radiologist familiar with SRS and is often suited to small cavities, many of which may be suited to primary SRS alone. Recent guidelines serve to maximise LC when choosing cavity SRS [37]. It is possible that fractionated conformal therapy offers the benefits of improve LC without WBRT associated neurotoxicity; however, this remains to be evaluated prospectively against SRS or observation. 


\subsection{The Role of Radiosurgery for Multiple Metastases}

Due to the aforementioned reasons, the use of WBRT has declined for patients with a favourable prognosis. With advances in SRS technology, the ability to efficiently treat a larger number of metastases has evolved and has become routine practice in a number of centres, although high quality evidence does not yet exist to support this approach. RCTs are currently open and evaluating the role of SRS alone versus WBRT for patients with multiple $(\geq 4)$ metastases with regards to quality of life and neuro-cognition primary endpoints. While awaiting these data to inform practice, we present a summary of the published clinical evidence.

Yamamoto et al. [38] present the largest observational series of patients treated with primary SRS alone and no previous WBRT. This paper demonstrated non-inferiority in OS between cohorts of patients treated with SRS for $2-4$ as compared to 5-10 metastases (10.8 months in both groups, $p=0.78$ ). LC and distant brain failure rates were also not significantly different between these cohorts; suggesting that the number of metastases does not influence the local control outcome or the likelihood of distant relapse in the brain. The risk of presenting with leptomeningeal disease however was significantly higher in those patients with the largest number of metastases (5-10). Notably, the median total volume of metastases was similar between the two cohorts with multiple metastases, illustrating the importance of the total volume of disease when selecting patients with more numerous metastases. Furthermore, these are often highly selected patients based on a favourable prognosis.

A number of retrospective series have also reported outcomes of patients treated with SRS for $\geq 4$ brain metastases with OS data presented in Table 1 for selected series. Notably, all of these series contain a proportion of patients treated with SRS for multiple metastases who had already received WBRT [39-42]. It is currently unknown whether the use of SRS upfront versus post WBRT differs in outcome.

Table 1. Retrospective series of patients with more than 4 metastases treated with SRS.

\begin{tabular}{cccccc}
\hline Reference & Year & $\begin{array}{c}\text { Number of } \\
\text { Metastases }\end{array}$ & $\begin{array}{c}\text { Number of } \\
\text { Patients }\end{array}$ & $\begin{array}{c}\text { 1 Year Rate of Distant } \\
\text { Brain Failure }\end{array}$ & $\begin{array}{c}\text { Median Overall } \\
\text { Survival (Months) }\end{array}$ \\
\hline \multirow{2}{*}{ Chang et al. [39] } & \multirow{2}{*}{2010} & $6-10$ & 58 & NR & 10 \\
& & $>15$ & 17 & $53.1 \%$ & 13 \\
\hline Mohammadi et al. [40] & 2012 & $5-20$ & 178 & $80.3 \%$ & $47.6 \%$ \\
Bhatnagar et al. [41] & 2006 & $4-18$ & 205 & $43 \%$ & 8 \\
\hline \multirow{2}{*}{ Raldow et al. [42] } & \multirow{2}{*}{2013} & $5-9$ & 84 & NR & 7.6 \\
& & $\geq 10$ & 19 & NR & 8.3 \\
\hline
\end{tabular}

NR: not reported.

It appears that survival outcomes for patients with multiple lesions treated with SRS are not inferior to those with fewer lesions; however, as with all single-centre, retrospective data, this is subject to bias and prospective evaluation is required. Many confounding variables influence the outcome in patients with multiple brain metastases, most importantly, performance status, age, histology, and whether the primary tumour or systemic disease is controlled. As such, it is not possible to recommend a single therapeutic option of either SRS alone or with WBRT at present. Patients with multiple metastases should be managed by a multi-disciplinary team with access to SRS. Those treated with SRS alone should receive a regular surveillance MRI, as rates of distant brain failure are high and salvage therapy should be offered (whether further SRS or WBRT) prior to neurological deterioration.

In conclusion, it is likely that both SRS and WBRT are important therapies in the management of patients with multiple brain metastases. However, the timing and combination of these still remain debatable. 


\subsection{Hypofractionated Stereotactic Radiotherapy}

For large lesions or lesions close to critical structures, the delivery of stereotactic radiotherapy in multiple fractions may be radiobiologically advantageous, due to the higher tolerances of normal tissues to fractionation. Table 2 details fifteen series employing 2-7 fractions of radiotherapy where 12 month local control rates ranging between $49 \%$ and $96 \%$ are reported [43-57]. Studies were excluded from Table 2 if 12-month LC outcomes were not analysed, or if hypofractionated stereotactic radiotherapy (hfSRT) was performed postoperatively to the tumour cavity, with these patients not being separated in the analysis [58-64].

Table 2. Fractionated stereotactic radiotherapy for brain metastasis series.

\begin{tabular}{|c|c|c|c|c|c|c|c|}
\hline Reference & Year & $\begin{array}{l}\text { No. of } \\
\text { Patients } \\
\text { (Lesions) }\end{array}$ & $\begin{array}{l}\text { Whole } \\
\text { Brain RT }\end{array}$ & $\begin{array}{c}\text { Median } \\
\text { Dose/Fraction }\end{array}$ & $\begin{array}{l}\text { Median GTV } \\
\left(\mathrm{cm}^{3}\right)\end{array}$ & $\begin{array}{l}\text { 12-Month Local } \\
\text { Control }\end{array}$ & $\begin{array}{c}\text { Size Specific } \\
\text { 12-Month Local } \\
\text { Control }\end{array}$ \\
\hline Aoyama et al. [43] & 2003 & $87(159)$ & $0(0 \%)$ & $35 \mathrm{~Gy} / 4 \#$ & $3.3(0.006-48.3)$ & $81 \%$ & $>3 \mathrm{~cm}^{3} 59 \%$ \\
\hline Ernst-Stecken et al. [44] & 2006 & $51(72)$ & $29(57 \%)^{A}$ & 30-35 Gy/5\# & $6(0.29-65.57)$ & $76 \%$ & NR \\
\hline Aoki et al. [45] & 2006 & $44(65)$ & $0(0 \%)$ & $24 \mathrm{~Gy} / 4 \#$ & NR & $72 \%$ & $>2 \mathrm{~cm}$ diameter $79 \%$ \\
\hline Narayana et al. [46] & 2007 & $20(20)$ & $0(0 \%)$ & $30 \mathrm{~Gy} / 5 \#$ & $3.5(2-5)$ & $70 \%$ & NR \\
\hline Giubilei et al. [47] & 2009 & $30(41)$ & $30(100 \%)^{A}$ & $18 \mathrm{~Gy} / 3 \#$ & $4.8(0.4-24.3)$ & $86 \%$ & $>2.1 \mathrm{~cm}$ diameter $80 \%$ \\
\hline Higuchi et al. [48] & 2009 & $43(46)$ & $0(0 \%)$ & $30 \mathrm{~Gy} / 3 \#$ & $17.6(10-35.5)$ & $76 \%$ & NR \\
\hline Kwon et al. [49] & 2009 & $27(52)$ & $\mathrm{NR}^{\mathrm{B}}$ & $25 \mathrm{~Gy} / 5 \#$ & NR & $68 \%$ & $>2 \mathrm{~cm}$ diameter $38 \%$ \\
\hline Kim et al. [50] & 2011 & $40(49)$ & $16(40 \%)$ & $36 \mathrm{~Gy} / 6 \#$ & NR & $69 \%$ & NR \\
\hline \multirow{2}{*}{ Fokas et al. [51] } & \multirow{2}{*}{2012} & $61(\mathrm{NR})$ & $0(0 \%)$ & $35 \mathrm{~Gy} / 7 \#$ & NR & $75 \%$ & NR \\
\hline & & 61 (NR) & $0(0 \%)$ & $40 \mathrm{~Gy} / 4 \#$ & NR & $71 \%$ & NR \\
\hline \multirow{3}{*}{ Märtens et al. [52] } & \multirow{3}{*}{2012} & $75(108)$ & $34(45 \%)^{\mathrm{C}}$ & $35 \mathrm{~Gy} / 7 \#$ & NR & $52 \%$ & NR \\
\hline & & $41(52)$ & $0(0 \%)$ & $35 \mathrm{~Gy} / 7 \#$ & $1(0.1-19)$ & $55 \%$ & NR \\
\hline & & $34(56)$ & $34(100 \%)^{C}$ & $30 \mathrm{~Gy} / 6 \#$ & $2(0.1-29.2)$ & $49 \%$ & NR \\
\hline Matsuyama et al. [53] & 2013 & 299 (NR) & $31(10 \%)^{\mathrm{D}}$ & 36 Gy/2\# & NR & $95 \%$ & $>2 \mathrm{~cm}$ diameter $85 \%$ \\
\hline Rajakesari et al. [54] & 2014 & 70 (NR) & $40(58 \%)^{\mathrm{E}}$ & $25 \mathrm{~Gy} / 5 \#$ & NR & $56 \%$ & NR \\
\hline Minniti et al. [55] & 2014 & $135(171)$ & $0(0 \%)$ & $27 \mathrm{~Gy} / 3 \#$ & $10.1(1.6-48.4)$ & $88 \%$ & NR \\
\hline Navarria et al. [56] & 2016 & $102(102)$ & $0(0 \%)$ & 27 Gy/3\#, 32 Gy/4\# & $16.3(3.9-64.5)$ & $96 \%$ & NR \\
\hline Marcrom et al. [57] & 2017 & $72(182)$ & $5(7 \%)^{\mathrm{F}}$ & $30 \mathrm{~Gy} / 5 \#$ & $2.02(0.01-39)$ & $86 \%$ & $\begin{array}{c}>3 \mathrm{~cm} \text { diameter } 61 \%, \\
>2 \mathrm{~cm} 74 \%\end{array}$ \\
\hline
\end{tabular}

RT: radiotherapy; GTV: gross tumour volume; Gy: Gray; \#: number of fractions; NR: not reported; A: WBRT followed by hfSRT boost; ${ }^{\mathrm{B}}$ : $45 / 52(86.5 \%)$ lesions treated with whole brain radiotherapy followed by hfSRT boost;

C: Median time from WBRT to hfSRT in months of 12.7 months $(0.5-28.8)$; ${ }^{\mathrm{D}}$ : Received WBRT before or after hfSRT;

E: 10 patients (14\%) treated with hfSRT within 3 months of WBRT; ${ }^{F}$ : Previous WBRT, not given to lesions of interest.

The data are difficult to interpret, as detail on the size of lesions treated is omitted in some series, and the use and size of a radiotherapy planning target volume (PTV) margin is variable. In addition, some series included patients who had received WBRT. In three series, where less than $10 \%$ of patients received WBRT, the rate of 12-month local control in patients with tumours $>2 \mathrm{~cm}$ control was $74-85 \%[45,53,57]$. In two series, where significant numbers of patients received WBRT, the corresponding range was $38-80 \%$ [47,49]. A comparison of late toxicity rates between these series is hampered by heterogeneity in reporting and definition. However, the rates of reported significant late toxicity appear low.

A pooled quantitative analysis of 10 retrospective studies of hfSRT demonstrated higher rates of local control when higher biological effective dose regimes were used [65]. Although hfSRT is in widespread use, a definitive prospective study to define appropriate dose, fractionation, and provide the evidence base for this treatment is desirable. Further retrospective studies are likely to be confounded by the factors described above.

\subsection{Combining Immunotherapy with SRS}

The ability to boost the immune response against malignant tumours has been one of most significant oncological advances in recent years. New agents are used to target checkpoint pathways, including the cytotoxic T-lymphocyte-associated antigen 4 (CTLA-4) pathway, which downregulates 
early T-cell function, and the programmed death 1 (PD-1) pathway, which regulates T-cell activity. Immune checkpoint inhibition (ICI) prevents the downregulation of T-cell activation and potentiates the anti-tumour response. Prolonged survival from metastatic disease has been demonstrated in several cancers, including melanoma, non-small cell lung cancer, and renal cell cancer [66-69]. Early RCTs excluded patients with brain metastases, but recent phase II data support that ICI can have an impact within the brain [70,71].

There has been significant debate with regards to a synergy between ICI and radiotherapy, including SRS. The immune cells including both T cells and myeloid cells are critical in mediating treatment response to radiotherapy [72-74]. Radiotherapy has been shown to induce the accumulation of myeloid-derived suppressive cells (MDSCs) and upregulate programmed death ligand 1 (PD-L1) expression in the tumour microenvironment, restricting its anti-tumour effect [75]. The addition of PD-1 antibody with radiotherapy has been shown to be synergistic in inhibiting tumour growth, as well as mediating an abscopal effect on distant non-irradiated tumours, by increasing CD8+ T cell response and reducing the local accumulation of MDSCs through the Tumour Necrosis Factor (TNF) [75]. In addition to preclinical models, PD-L1 expression and tumour-infiltrating lymphocytes have been found in brain metastasis samples across several solid tumour sites supporting the hypothesis of benefit from targeting this pathway [76-78].

Although an early retrospective series evaluating a mixture of systemic therapies suggested an increased risk of toxicity with concurrent ICI [79], evidence is now mounting in favour of a combination approach. A single prospective phase I study has confirmed the short-term safety of the CTLA-4 antibody ipilimumab with SRS [80]. Several retrospective series have also reported the safety profile of SRS with ipilimumab to be similar to SRS alone [81-86]. Some studies have suggested outcomes were better with a combined approach of ipilimumab and SRS $[83,86,87]$. A combined institutional analysis of 99 patients with metastatic melanoma reported improved intracranial control using SRS within 5.5 months of ipilimumab (median 3.63 vs. 8.09 months, hazard ratio (HR) 2.07, 95\% CI, 1.03-4.16, $p=0.041$ ) [87]. In another study of SRS for melanoma patients with brain metastases, concurrent treatment with ipilimumab improved local control compared to sequential treatment of SRS after ipilimumab [86].

Prospective data of anti-PD1 therapy with SRS is lacking, but an analysis combining data from 2 prospective trials of patients with melanoma looked at 26 patients with brain metastases treated with SRS within 6 months of receiving nivolumab (either before, during, or after nivolumab administration). There was one grade 2 headache following SRS, but no other treatment-related neurological toxicities [88]. Several retrospective cohorts have reported acceptable toxicity and possible advantages in combining anti-PD1 therapy with SRS [89-91]. One retrospective study evaluated 623 brain metastases within 260 patients and used multivariate analysis (MVA) to explore the impact of sequencing and type of ICI [89]. Using MVA, OS for patients treated with SRS/SRT and concurrent ICI was significantly higher than with non-concurrent SRS/SRT $(p=0.006)$ and SRS/SRT alone $(p=0.002)$. OS was also better for patients receiving anti PD1 therapy compared to anti CTLA-4 therapy $(p=0.004)$. Concurrent ICI reduced the likelihood of new brain metastases $(p=0.045)$.

Phase III data have shown that combination CTLA-4 and PD-1 inhibition improves progression-free survival within melanoma establishing a new standard of care [67]. Phase II data have recently been reported to suggest that this combination approach also gives a greater response within the brain, leading some to question the need for radiotherapy [70]. However, the durability of local control with ICI therapy alone compared to SRS remains unclear. It is possible that combination ICI with SRS offers the optimum outcome with regards to intracranial control, and such a strategy is currently under evaluation for patients with limited melanoma brain metastases [92].

Available data to guide decisions using ICI with SRS are retrospective, subject to multiple confounding variables, and complicated by a dynamic landscape with regards to the licensing of new agents and combinations. It is important that SRS be incorporated into prospective studies and that patients with brain metastases are not automatically excluded from the evaluation of new agents. 


\subsection{Response Assessment Following Radiosurgery}

Serial structural Magnetic Resonance Imaging (MRI) remains the standard method of assessing response following SRS to brain metastases. However, in assessing response to SRS, structural MRI is reliant upon contrast enhancement pattern changes and alterations in T2/fluid-attenuated inversion recovery (FLAIR) weighting, which cannot sufficiently differentiate local tumour recurrence from SRS-induced changes [93]. In a series of 500 brain metastases treated with SRS, Patel et al. reported that one-third of the lesions had a transient size increase following treatment, starting as early as six weeks, and could be observed up to 15 months post-SRS [94]. It is estimated that between $30-75 \%$ of radiographically enlarging SRS-treated brain metastases are due to radiation-related changes alone [95-100]. In recognition of the increasing proportion of patients with brain metastases treated with a more aggressive local treatment and the increasing inclusion of this patient cohort in clinical trials, the international multidisciplinary Response Assessment in Neuro-Oncology Brain Metastases (RANO-BM) working group has published a guideline on standard response and progression criteria based on MRI [93]. However, the guidelines acknowledge the challenges in response assessment following SRS, recommending a short interval follow-up MRI in situations of uncertainty and the consideration of more advanced tests dependent upon local experience.

The use of MRI with delayed contrast extravasation more than one hour following a contrast injection has been reported to show differentiation between tumour recurrence and radiation changes [101]. Zach et al. used delayed contrast to develop treatment response assessment maps for both primary and metastatic brain tumours. The study included 26 brain metastases evaluated with histological correlation and sensitivity/PPV for active tumour was reported as $100 \% / 89 \%$. Other advanced MRI methods that can monitor the physiological and metabolic properties of tumour are being investigated to help distinguish radiation change from progression. These include diffusion-weighted imaging (DWI), perfusion-weighted imaging (PWI), and MR spectroscopy (MRS). The authors have been investigating the use of apparent diffusion coefficient (ADC), relative cerebral blood volume ( $\mathrm{rCBV}$ ) and the relative metabolite levels, particularly the choline to creatinine ratio from MR spectroscopy (Cho:Cr). Although there is data supporting the utility of each of these methods $[95,96,98,100]$, limitations remain such that no single method is currently validated. It is possible that a combination multiparametric MRI protocol may provide a higher degree of confidence in gauging brain metastasis response post-SRS; however, prospective validation is required.

\subsection{Radiosurgery Technical Developments}

As discussed above, based on the available evidence, there is a trend away from WBRT and towards the use of SRS for multiple metastases. With modern dedicated SRS platforms, such as Gamma Knife and Cyberknife, it is possible to routinely treat multiple metastases in a single session (see Figure 2). Linear accelerators are more readily available than dedicated SRS machines and are also capable of delivering highly conformal therapy with increasing accuracy. Exploiting such readily available technology may help to meet the rising demand for SRS to brain metastases. Other advantages include the speed with which patients could be treated using techniques such as volumetric modulated arc therapy (VMAT) and the avoidance of surgical immobilisation. A summary of selected technical differences between SRS platforms is given in Table 3.

Conventional linear accelerator SRS uses several beams or arcs to treat individual targets at the isocentre and can prove inefficient when treating multiple metastases [102]. HyperarcTM (Varian Medical System Inc., Palo Alto, CA, USA) is a recent software development automating the delivery of multiple non-coplanar VMAT arcs to several targets around a single isocentre, thereby avoiding the need for verification at each isocentre [103,104]. HyperArcTM has been shown to be capable of delivering a higher Conformity Index, Gradient Index, and reduced treatment times compared to conventional multiple isocentre VMAT SRS [103]. At treatment planning level this single isocentre VMAT technique can achieve similar dose metrics to Gamma Knife and cyberknife for multiple metastases [102,104]. However, dedicated SRS machines such as Cyberknife and Gamma Knife 
routinely deliver treatment without the application of an uncertainty margin, including without surgical immobilisation, and this factor has to be taken into account.

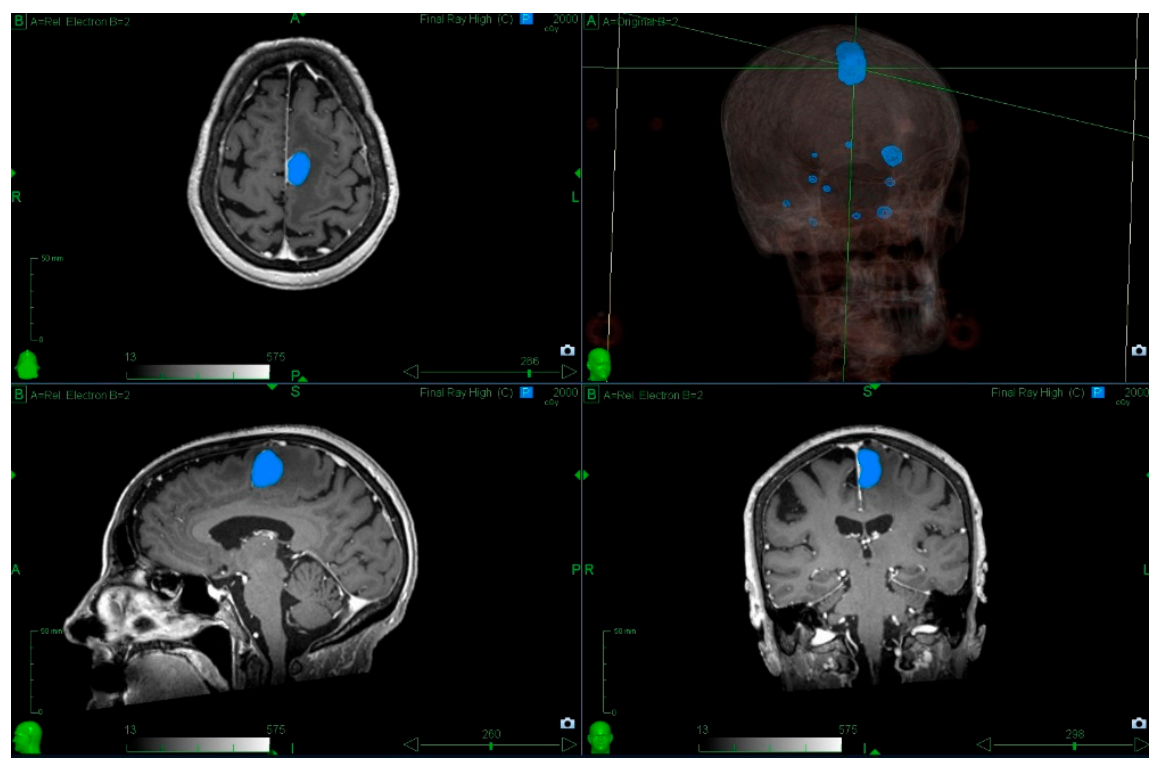

Figure 2. Radiosurgery to multiple metastases. The patient was referred with a symptomatic left frontal lobe metastasis; however, there were 11 metastases in total, and it was possible to treat all within a single session. The blue outline indicates the $20 \mathrm{~Gy}$ isodose (minimum dose prescribed to the left frontal lobe metastasis). Prior informed consent has been obtained for use of these images.

Adapted conventional machines, with a comprehensive quality assurance programme, can achieve a 1-mm positional uncertainty for frameless deliveries with interfraction imaging [105]. For the treatment of multiple metastases, however, single isocentre treatments can lead to a magnification of spatial positioning uncertainties at increasing distances from the isocentre [106]. This leads to the requirement to add a CTV-PTV margin in order to ensure target coverage, which may be up to $2 \mathrm{~mm}$ for distant lesions [106]. Studies using non-invasive head frames and cone beam CT imaging have been shown to be able to achieve millimetre accuracy, but even with these systems, there is reluctance to treat metastases in eloquent locations [107]. Although there will be inherent uncertainties to all systems, the application of a margin must be considered carefully, given that it may be associated with an increased risk of toxicity [108]. Many of the published series to date have used platforms that have not applied a margin, establishing a reference standard of care. The combined steep gradient achievable via conical collimation and the ability to treat without a margin still makes these dedicated platforms highly suited for small multiple lesions.

Table 3. Technical differences between radiosurgery platforms.

\begin{tabular}{cccc}
\hline Platform Attributes & Modified Accelerator & CyberKnife & GammaKnife \\
\hline Imaging Capability & $\begin{array}{c}\text { Cone beam CT and } \\
\text { Planar x-rays }\end{array}$ & Planar x-rays & Cone beam CT and optical monitoring \\
\hline Advantages & $\begin{array}{c}\text { Inter-fraction } \\
\text { compensation }\end{array}$ & $\begin{array}{c}\text { Intra-fraction movement } \\
\text { compensation with no patient } \\
\text { repositioning }\end{array}$ & $\begin{array}{c}\text { Intra-fraction monitoring when using } \\
\text { relocatable headframe }\end{array}$ \\
\cline { 2 - 4 } prolonged fractionation & $\begin{array}{c}\text { Hypofractionation } \\
\text { Patient movement } \\
\text { required to compensate } \\
\text { intra-fraction shifts }\end{array}$ & $\begin{array}{c}\text { Imaging dose during } \\
\text { treatment }\end{array}$ & $\begin{array}{c}\text { Intra-fraction imaging using optical } \\
\text { surrogate. Patient movement required to } \\
\text { compensate intra-fraction shifts }\end{array}$ \\
\hline
\end{tabular}


Table 3. Cont.

\begin{tabular}{cccc}
\hline Platform Attributes & Modified Accelerator & CyberKnife & GammaKnife \\
\hline Beam Delivery & Micro MLC & Cones, MLC & Cones \\
\hline Advantages & $\begin{array}{c}\text { Homogenous dose } \\
\text { distribution. } \\
\text { Speed of delivery }\end{array}$ & High dose conformality & $\begin{array}{c}\text { High dose conformality. } \\
\text { Lowest extracranial dose }\end{array}$ \\
\hline Disadvantages & $\begin{array}{c}\text { Reduced dose } \\
\text { conformality }\end{array}$ & $\begin{array}{c}\text { Inhomogeneous dose } \\
\text { distribution. } \\
\text { Prolonged delivery }\end{array}$ & Inhomogeneous dose distribution. \\
\hline Geometric positioning & $\begin{array}{c}\text { Gantry Mounted } \\
\text { accelerator. Headframe }\end{array}$ & $\begin{array}{c}\text { Robotic Mounted accelerator. } \\
\text { Immobilisation shell }\end{array}$ & $\begin{array}{c}\text { Static system. } \\
\text { Relocatable headframe }\end{array}$ \\
\hline Advantages & Arc therapy & $\begin{array}{c}\text { Geometric precision }<0.5 \mathrm{~mm} \\
\text { No PTV margin }\end{array}$ & $\begin{array}{c}\text { Geometric precision }<0.5 \text { mm } \\
\text { No PTV margin }\end{array}$ \\
\hline Disadvantages & $\begin{array}{c}\text { Geometric uncertainty } \\
\text { typically } 1 \mathrm{~mm}\end{array}$ & $\begin{array}{c}\text { Limited ability to deliver } \\
\text { posterior beams }\end{array}$ & $\begin{array}{c}\text { Headframe. } \\
\text { Delivery restricted to intra-cranial targets }\end{array}$ \\
\hline
\end{tabular}

CT: Computed Tomography; MLC: Multi-leaf collimator; PTV: Planning Target Volume.

\section{Summary}

SRS is being increasingly recognised as a valuable treatment option in the management of patients with brain metastases. Improvements in systemic disease control combined with recognition of WBRT toxicity have led to SRS becoming considered a standard of care in patients with 1-3 metastases. Surgical cavity SRS offers lower rates of neurocognitive deterioration at 6 months compared with postoperative WBRT, and despite inferior local control, survival rates are equivalent. Technical developments in planning have enabled treatments to be delivered to a greater number of metastases in a single session, whereas fractionating treatment may permit the treatment of larger volume lesions. Immunotherapy has changed the landscape for several cancers with a propensity to spread to the brain, and there may be a synergistic effect with SRS. Response assessment following SRS is complicated by post radiation change. Although advanced imaging techniques may aid its interpretation, it is difficult to recommend any single modality at present. Patients with brain metastases should be managed collaboratively by neuroscience centres having expertise in SRS, neurosurgery, and specialist imaging.

Funding: This research received no external funding.

Conflicts of Interest: The authors currently undertake radiosurgery for brain metastases using Cyberknife.

\section{References}

1. Leksell, L. The stereotaxic method and radiosurgery of the brain. Acta Chir. Scand. 1951, 1002, 316-319.

2. Winston, K.R.; Lutz, W. Linear accelerator as a neurosurgical tool for stereotactic radiosurgery. Neurosurgery 1988, 22, 454-464. [CrossRef] [PubMed]

3. Frisk, G.; Svensson, T.; Bäcklund, L.M.; Lidbrink, E.; Blomqvist, P.; Smedby, K.E. Incidence and time trends of brain metastases admissions among breast cancer patients in Sweden. Br. J. Cancer 2012, 106, 1850-1853. [CrossRef] [PubMed]

4. Schouten, L.J.; Rutten, J.; Huveneers, H.A.; Twijnstra, A. Incidence of brain metastases in a cohort of patients with carcinoma of the breast, colon, kidney, and lung and melanoma. Cancer 2002, 94, 2698-2705. [CrossRef] [PubMed]

5. Kondziolka, D.; Patel, A.; Lunsford, L.D.; Kassam, A.; Flickinger, J.C. Stereotactic radiosurgery plus whole brain radiotherapy versus radiotherapy alone for patients with multiple brain metastases. Int. J. Radiat. Oncol. 1999, 45, 427-434. [CrossRef]

6. Andrews, D.W.; Scott, C.B.; Sperduto, P.W.; Flanders, A.E.; Gaspar, L.E.; Schell, M.C.; Werner-Wasik, M.; Demas, W.; Ryu, J.; Bahary, J.P.; et al. Whole brain radiation therapy with or without stereotactic radiosurgery boost for patients with one to three brain metastases: Phase III results of the RTOG 9508 randomised trial. Lancet 2004, 363, 1665-1672. [CrossRef] 
7. Lagerwaard, F.J.; Levendag, P.C.; Nowak, P.J.; Eijkenboom, W.M.; Hanssens, P.E.; Schmitz, P.I. Identification of prognostic factors in patients with brain metastases: A review of 1292 patients. Int. J. Radiat. Oncol. 1999, 43, 795-803. [CrossRef]

8. Weltman, E.; Salvajoli, J.V.; Brandt, R.A.; de Morais Hanriot, R.; Prisco, F.E.; Cruz, J.C.; de Oliveira Borges, S.R.; Wajsbrot, D.B. Radiosurgery for brain metastases: A score index for predicting prognosis. Int. J. Radiat. Oncol. Biol. Phys. 2000, 46, 1155-1161. [CrossRef]

9. Lorenzoni, J.; Devriendt, D.; Massager, N.; David, P.; Ruíz, S.; Vanderlinden, B.; Van Houtte, P.; Brotchi, J.; Levivier, M. Radiosurgery for treatment of brain metastases: Estimation of patient eligibility using three stratification systems. Int. J. Radiat. Oncol. Biol. Phys. 2004, 60, 218-224. [CrossRef] [PubMed]

10. Sperduto, P.W.; Berkey, B.; Gaspar, L.E.; Mehta, M.; Curran, W. A new prognostic index and comparison to three other indices for patients with brain metastases: An analysis of 1,960 patients in the RTOG database. Int. J. Radiat. Oncol. Biol. Phys. 2008, 70, 510-514. [CrossRef] [PubMed]

11. Golden, D.W.; Lamborn, K.R.; McDermott, M.W.; Kunwar, S.; Wara, W.M.; Nakamura, J.L.; Sneed, P.K. Prognostic factors and grading systems for overall survival in patients treated with radiosurgery for brain metastases: Variation by primary site. J. Neurosurg. 2008, 109, 77-86. [CrossRef] [PubMed]

12. Sperduto, P.W.; Chao, S.T.; Sneed, P.K.; Luo, X.; Suh, J.; Roberge, D.; Bhatt, A.; Jensen, A.W.; Brown, P.D.; Shih, H.; et al. Diagnosis-specific prognostic factors, indexes, and treatment outcomes for patients with newly diagnosed brain metastases: A multi-institutional analysis of 4259 patients. Int. J. Radiat. Oncol. Biol. Phys. 2010, 77, 655-661. [CrossRef] [PubMed]

13. Rades, D.; Dziggel, L.; Haatanen, T.; Veninga, T.; Lohynska, R.; Dunst, J.; Schild, S.E. Scoring systems to estimate intracerebral control and survival rates of patients irradiated for brain metastases. Int. J. Radiat. Oncol. Biol. Phys. 2011, 80, 1122-1127. [CrossRef] [PubMed]

14. Gaspar, L.; Scott, C.; Rotman, M.; Asbell, S.; Phillips, T.; Wasserman, T.; McKenna, W.G.; Byhardt, R. Recursive partitioning analysis (RPA) of prognostic factors in three Radiation Therapy Oncology Group (RTOG) brain metastases trials. Int. J. Radiat. Oncol. Biol. Phys. 1997, 37, 745-751. [CrossRef]

15. Zindler, J.D.; Rodrigues, G.; Haasbeek, C.J.A.; De Haan, P.F.; Meijer, O.W.M.; Slotman, B.J.; Lagerwaard, F.J. The clinical utility of prognostic scoring systems in patients with brain metastases treated with radiosurgery. Radiother. Oncol. 2013, 106, 370-374. [CrossRef] [PubMed]

16. Sperduto, P.W.; Jiang, W.; Brown, P.D.; Braunstein, S.; Sneed, P.; Wattson, D.A.; Shih, H.A.; Bangdiwala, A.; Shanley, R.; Lockney, N.A.; et al. Estimating survival in melanoma patients with brain metastases: An update of the Graded Prognostic Assessment for melanoma using molecular markers (Melanoma-molGPA). Int. J. Radiat. Oncol. Biol. Phys. 2017, 99, 812-816. [CrossRef] [PubMed]

17. Sperduto, P.W.; Yang, T.J.; Beal, K.; Pan, H.; Brown, P.D.; Bangdiwala, A.; Shanley, R.; Yeh, N.; Gaspar, L.E.; Braunstein, S.; et al. Estimating survival in patients with lung cancer and brain metastases: An update of the Graded Prognostic Assessment for lung cancer using molecular markers (Lung-molGPA). JAMA Oncol. 2017, 3, 827-831. [CrossRef] [PubMed]

18. Brown, P.D.; Ahluwalia, M.S.; Khan, O.H.; Asher, A.L.; Wefel, J.S.; Gondi, V. Whole-brain radiotherapy for brain metastases: Evolution or revolution? J. Clin. Oncol. 2018, 36, 483-491. [CrossRef] [PubMed]

19. Borgelt, B.; Gelber, R.; Kramer, S.; Brady, L.W.; Chang, C.H.; Davis, L.W.; Perez, C.A.; Hendrickson, F.R. The palliation of brain metastases: Final results of the first two studies by the radiation therapy oncology group. Int. J. Radiat. Oncol. Biol. Phys. 1980, 6, 1-9. [CrossRef]

20. Pinkham, M.B.; Sanghera, P.; Wall, G.K.; Dawson, B.D.; Whitfield, G.A. Neurocognitive effects following cranial irradiation for brain metastases. Clin. Oncol. 2015, 27, 630-639. [CrossRef] [PubMed]

21. Meyers, C.A.; Smith, J.A.; Bezjak, A.; Mehta, M.P.; Liebmann, J.; Illidge, T.; Kunkler, I.; Caudrelier, J.-M.; Eisenberg, P.D.; Meerwaldt, J.; et al. Neurocognitive function and progression in patients with brain metastases treated with whole-brain radiation and motexafin gadolinium: Results of a randomized phase III trial. J. Clin. Oncol. 2004, 22, 157-165. [CrossRef] [PubMed]

22. Regine, W.F.; Scott, C.; Murray, K.; Curran, W. Neurocognitive outcome in brain metastases patients treated with accelerated-fractionation vs. accelerated-hyperfractionated radiotherapy: An analysis from Radiation Therapy Oncology Group Study 91-04. Int. J. Radiat. Oncol. Biol. Phys. 2001, 51, 711-717. [CrossRef] 
23. Corn, B.W.; Moughan, J.; Knisely, J.P.S.; Fox, S.W.; Chakravarti, A.; Yung, W.K.A.; Curran, W.J., Jr.; Robins, H.I.; Brachman, D.G.; Henderson, R.H.; et al. Prospective evaluation of quality of life and neurocognitive effects in patients with multiple brain metastases receiving whole-brain radiotherapy with or without thalidomide on Radiation Therapy Oncology Group (RTOG) trial 0118. Int. J. Radiat. Oncol. Biol. Phys. 2008, 71, 71-78. [CrossRef] [PubMed]

24. Sanghera, P.; Gardner, S.L.; Scora, D.; Davey, P. Early expansion of the intracranial CSF volume after palliative whole-brain radiotherapy: Results of a longitudinal CT segmentation analysis. Int. J. Radiat. Oncol. Biol. Phys. 2010, 76, 1171-1176. [CrossRef] [PubMed]

25. Aoyama, H.; Shirato, H.; Tago, M.; Nakagawa, K.; Toyoda, T.; Hatano, K.; Kenjyo, M.; Oya, N.; Hirota, S.; Shioura, H.; et al. Stereotactic radiosurgery plus whole-brain radiation therapy vs stereotactic radiosurgery alone for treatment of brain metastases: A randomized controlled trial. JAMA 2006, 295, 2483-2491. [CrossRef] [PubMed]

26. Meyers, C.A.; Wefel, J.S. The use of the mini-mental state examination to assess cognitive functioning in cancer trials: No ifs, ands, buts, or sensitivity. J. Clin. Oncol. 2003, 21, 3557-3558. [CrossRef] [PubMed]

27. Chang, E.L.; Wefel, J.S.; Hess, K.R.; Allen, P.K.; Lang, F.F.; Kornguth, D.G.; Arbuckle, R.B.; Swint, J.M.; Shiu, A.S.; Maor, M.H.; et al. Neurocognition in patients with brain metastases treated with radiosurgery or radiosurgery plus whole-brain irradiation: A randomised controlled trial. Lancet Oncol. 2009, 10, 1037-1044. [CrossRef]

28. Brown, P.D.; Jaeckle, K.; Ballman, K.V.; Farace, E.; Cerhan, J.H.; Anderson, S.K.; Carrero, X.W.; Barker II, F.G.; Deming, R.; Burri, S.H.; Ménard, C.; et al. Effect of radiosurgery alone vs radiosurgery with whole brain radiation therapy on cognitive function in patients with 1 to 3 brain metastases: A randomized clinical trial. JAMA 2016, 316, 401-409. [CrossRef] [PubMed]

29. Kocher, M.; Soffietti, R.; Abacioglu, U.; Villà, S.; Fauchon, F.; Baumert, B.G.; Fariselli, L.; TzukShina, T.; Kortmann, R.D.; Carrie, C.; et al. Adjuvant whole-brain radiotherapy versus observation after radiosurgery or surgical resection of one to three cerebral metastases: Results of the EORTC 22952-26001 study. J. Clin. Oncol. 2011, 29, 134-141. [CrossRef] [PubMed]

30. Soffietti, R.; Kocher, M.; Abacioglu, U.M.; Villa, S.; Fauchon, F.; Baumert, B.G.; Fariselli, L.; Tzuk-Shina, T.; Kortmann, R.D.; Carrie, C.; et al. A European Organisation for Research and Treatment of Cancer phase III trial of adjuvant whole-brain radiotherapy versus observation in patients with one to three brain metastases from solid tumors after surgical resection or radiosurgery: Quality-of-life results. J. Clin. Oncol. 2013, 31, 65-72. [CrossRef] [PubMed]

31. Sahgal, A.; Aoyama, H.; Kocher, M.; Neupane, B.; Collette, S.; Tago, M.; Shaw, P.; Beyene, J.; Chang, E.L. Phase 3 trials of stereotactic radiosurgery with or without whole-brain radiation therapy for 1 to 4 brain metastases: Individual patient data meta-analysis. Int. J. Radiat. Oncol. Biol. Phys. 2015, 91, 710-717. [CrossRef] [PubMed]

32. Aoyama, H.; Tago, M.; Shirato, H.; for the Japanese Radiation Oncology Study Group 99-1 (JROSG 99-1) Investigators. Stereotactic radiosurgery with or without whole-brain radiotherapy for brain metastases: Secondary analysis of the JROSG 99-1 randomized clinical trial. JAMA Oncol. 2015, 1, 457-464. [CrossRef] [PubMed]

33. Roos, D.E.; Smith, J.G.; Stephens, S.W. Radiosurgery versus surgery, both with adjuvant whole brain radiotherapy, for solitary brain metastases: A randomised controlled trial. Clin. Oncol. 2011, 23, 646-651. [CrossRef] [PubMed]

34. Mahajan, A.; Ahmed, S.; McAleer, M.F.; Weinberg, J.S.; Li, J.; Brown, P.; Settle, S.; Prabhu, S.S.; Lang, F.F.; Levine, N.; et al. Post-operative stereotactic radiosurgery versus observation for completely resected brain metastases: A single-centre, randomised, controlled, phase 3 trial. Lancet Oncol. 2017, 18, 1040-1048. [CrossRef]

35. Brown, P.D.; Ballman, K.V.; Cerhan, J.H.; Anderson, S.K.; Carrero, X.W.; Whitton, A.C.; Greenspoon, J.; Parney, I.F.; Laack, N.N.I.; Ashman, J.B.; et al. Postoperative stereotactic radiosurgery compared with whole brain radiotherapy for resected metastatic brain disease (NCCTG N107C/CEC•3): A multicentre, randomised, controlled, phase 3 trial. Lancet Oncol. 2017, 18, 1049-1060. [CrossRef] 
36. Kepka, L.; Tyc-Szczepaniak, D.; Bujko, K.; Olszyna-Serementa, M.; Michalski, W.; Sprawka, A.; Trabska-Kluch, B.; Komosińska, K.; Wasilewska-Teśluk, E.; Czeremszynska, B. Stereotactic radiotherapy of the tumor bed compared to whole brain radiotherapy after surgery of single brain metastasis: Results from a randomized trial. Radiother. Oncol. 2016, 121, 217-224. [CrossRef] [PubMed]

37. Soliman, H.; Ruschin, M.; Angelov, L.; Brown, P.D.; Chiang, V.L.S.; Kirkpatrick, J.P.; Lo, S.S.; Mahajan, A.; Oh, K.S.; Sheehan, J.P.; et al. Consensus contouring guidelines for postoperative completely resected cavity stereotactic radiosurgery for brain metastases. Int. J. Radiat. Oncol. Biol. Phys. 2018, 100, 436-442. [CrossRef] [PubMed]

38. Yamamoto, M.; Serizawa, T.; Shuto, T.; Akabane, A.; Higuchi, Y.; Kawagishi, J.; Yamanaka, K.; Sato, Y.; Jokura, H.; Yomo, S.; et al. Stereotactic radiosurgery for patients with multiple brain metastases (JLGK0901): A multi-institutional prospective observational study. Lancet Oncol. 2014, 15, 387-395. [CrossRef]

39. Chang, W.S.; Kim, H.Y.; Chang, J.W.; Park, Y.G.; Chang, J.H. Analysis of radiosurgical results in patients with brain metastases according to the number of brain lesions: Is stereotactic radiosurgery effective for multiple brain metastases? J. Neurosurg. 2010, 113, 73-78. [CrossRef] [PubMed]

40. Mohammadi, A.M.; Recinos, P.F.; Barnett, G.H.; Weil, R.J.; Vogelbaum, M.A.; Chao, S.T.; Suh, J.H.; Marko, N.F.; Elson, P.; Neyman, G.; et al. Role of Gamma Knife surgery in patients with 5 or more brain metastases. J. Neurosurg. 2012, 117, 5-12. [CrossRef] [PubMed]

41. Bhatnagar, A.K.; Flickinger, J.C.; Kondziolka, D.; Lunsford, L.D. Stereotactic radiosurgery for four or more intracranial metastases. Int. J. Radiat. Oncol. Biol. Phys. 2006, 64, 898-903. [CrossRef] [PubMed]

42. Raldow, A.C.; Chiang, V.L.; Knisely, J.P.; Yu, J.B. Survival and intracranial control of patients with 5 or more brain metastases treated with gamma knife stereotactic radiosurgery. Am. J. Clin. Oncol. 2013, 36, 486-490. [CrossRef] [PubMed]

43. Aoyama, H.; Shirato, H.; Onimaru, R.; Kagei, K.; Ikeda, J.; Ishii, N.; Sawamura, Y.; Miyasaka, K. Hypofractionated stereotactic radiotherapy alone without whole-brain irradiation for patients with solitary and oligo brain metastasis using noninvasive fixation of the skull. Int. J. Radiat. Oncol. Biol. Phys. 2003, 56, 793-800. [CrossRef]

44. Ernst-Stecken, A.; Ganslandt, O.; Lambrecht, U.; Sauer, R.; Grabenbauer, G. Phase II trial of hypofractionated stereotactic radiotherapy for brain metastases: Results and toxicity. Radiother. Oncol. 2006, 81, 18-24. [CrossRef] [PubMed]

45. Aoki, M.; Abe, Y.; Hatayama, Y.; Kondo, H.; Basaki, K. Clinical outcome of hypofractionated conventional conformation radiotherapy for patients with single and no more than three metastatic brain tumors, with noninvasive fixation of the skull without whole brain irradiation. Int. J. Radiat. Oncol. Biol. Phys. 2006, 64, 414-418. [CrossRef] [PubMed]

46. Narayana, A.; Chang, J.; Yenice, K.; Chan, K.; Lymberis, S.; Brennan, C.; Gutin, P.H. Hypofractionated stereotactic radiotherapy using intensity-modulated radiotherapy in patients with one or two brain metastases. Stereotact. Funct. Neurosurg. 2007, 85, 82-87. [CrossRef] [PubMed]

47. Giubilei, C.; Ingrosso, G.; Andrea, M.; Benassi, M.; Santoni, R. Hypofractionated stereotactic radiotherapy in combination with whole brain radiotherapy for brain metastases. J. Neurooncol. 2009, 91, 207-212. [CrossRef] [PubMed]

48. Higuchi, Y.; Serizawa, T.; Nagano, O.; Matsuda, S.; Ono, J.; Sato, M.; Iwadate, Y.; Saeki, N. Three-staged stereotactic radiotherapy without whole brain irradiation for large metastatic brain tumors. Int. J. Radiat. Oncol. Biol. Phys. 2009, 74, 1543-1548. [CrossRef] [PubMed]

49. Kwon, A.K.; Dibiase, S.J.; Wang, B.; Hughes, S.L.; Milcarek, B.; Zhu, Y. Hypofractionated stereotactic radiotherapy for the treatment of brain metastases. Cancer 2009, 115, 890-898. [CrossRef] [PubMed]

50. Kim, Y.-J.; Cho, K.H.; Kim, J.-Y.; Lim, Y.K.; Min, H.S.; Lee, S.H.; Kim, H.J.; Gwak, H.S.; Yoo, H.; Lee, S.H. Single-dose versus fractionated stereotactic radiotherapy for brain metastases. Int. J. Radiat. Oncol. Biol. Phys. 2011, 81, 483-489. [CrossRef] [PubMed]

51. Fokas, E.; Henzel, M.; Surber, G.; Kleinert, G.; Hamm, K.; Engenhart-Cabillic, R. Stereotactic radiosurgery and fractionated stereotactic radiotherapy: Comparison of efficacy and toxicity in 260 patients with brain metastases. J. Neurooncol. 2012, 109, 91-98. [CrossRef] [PubMed]

52. Märtens, B.; Janssen, S.; Werner, M.; Frühauf, J.; Christiansen, H.; Bremer, M.; Steinmann, D. Hypofractionated stereotactic radiotherapy of limited brain metastases: A single-centre individualized treatment approach. BMC Cancer 2012, 12, 497. [CrossRef] [PubMed] 
53. Matsuyama, T.; Kogo, K.; Oya, N. Clinical outcomes of biological effective dose-based fractionated stereotactic radiation therapy for metastatic brain tumors from non-small cell lung cancer. Int. J. Radiat. Oncol. Biol. Phys. 2013, 85, 984-990. [CrossRef] [PubMed]

54. Rajakesari, S.; Arvold, N.D.; Jimenez, R.B.; Christianson, L.W.; Horvath, M.C.; Claus, E.B.; Golby, A.J.; Johnson, M.D.; Dunn, I.F.; Lee, E.Q.; et al. Local control after fractionated stereotactic radiation therapy for brain metastases. J. Neurooncol. 2014, 120, 339-346. [CrossRef] [PubMed]

55. Minniti, G.; D’Angelillo, R.M.; Scaringi, C.; Trodella, L.E.; Clarke, E.; Matteucci, P.; Osti, M.F.; Ramella, S.; Enrici, R.M.; Trodella, L. Fractionated stereotactic radiosurgery for patients with brain metastases. J. Neurooncol. 2014, 117, 295-301. [CrossRef] [PubMed]

56. Navarria, P.; Pessina, F.; Cozzi, L.; Ascolese, A.M.; De Rose, F.; Fogliata, A.; Franzese, C.; Franceschini, D.; Tozzi, A.; D'Agostino, G.; et al. Hypo-fractionated stereotactic radiotherapy alone using volumetric modulated arc therapy for patients with single, large brain metastases unsuitable for surgical resection. Radiat. Oncol. 2016, 11, 76. [CrossRef] [PubMed]

57. Marcrom, S.R.; McDonald, A.M.; Thompson, J.W.; Popple, R.A.; Riley, K.O.; Markert, J.M.; Willey, C.D.; Bredel, M.; Fiveash, J.B. Fractionated stereotactic radiation therapy for intact brain metastases. Adv. Radiat. Oncol. 2017, 2, 564-571. [CrossRef] [PubMed]

58. Eaton, B.; Gebhardt, B.; Prabhu, R.; Shu, H.; Curran, W.; Crocker, I. Hypofractionated radiosurgery for intact or resected brain metastases: Defining the optimal dose and fractionation. Radiat. Oncol. 2013, 8, 135. [CrossRef] [PubMed]

59. Manning, M.; Cardinale, R.; Benedict, S. Hypofractionated stereotactic radiotherapy as an alternative to radiosurgery for the treatment of patients with brain metastases. Int. J. Radiat. Oncol. Biol. Phys. 2000, 47, 603-608. [CrossRef]

60. Lindvall, P.; Bergström, P.; Löfroth, P.O.; Henriksson, R.; Bergenheim, A.T. Hypofractionated conformal stereotactic radiotherapy alone or in combination with whole-brain radiotherapy in patients with cerebral metastases. Int. J. Radiat. Oncol. Biol. Phys. 2005, 61, 1460-1466. [CrossRef] [PubMed]

61. Fahrig, A.; Ganslandt, O.; Lambrecht, U.; Grabenbauer, G.; Kleinert, G.; Sauer, R.; Hamm, K. Hypofractionated stereotactic radiotherapy for brain metastases. Strahlenther. Onkol. 2007, 183, 625-630. [CrossRef] [PubMed]

62. Kim, J.W.; Park, H.R.; Lee, J.M.; Kim, J.W.; Chung, H.T.; Kim, D.G.; Jung, H.W.; Paek, S.H. Fractionated stereotactic Gamma Knife radiosurgery for large brain metastases: A retrospective, single center study. PLoS ONE 2016, 11, e0163304. [CrossRef] [PubMed]

63. Lockney, N.A.; Wang, D.G.; Gutin, P.H.; Brennan, C.; Tabar, V.; Ballangrud, A.; Pei, X.; Chan, T.A.; Yamada, Y.; Yang, T.J.; et al. Clinical outcomes of patients with limited brain metastases treated with hypofractionated (5 × 6 Gy) conformal radiotherapy. Radiother. Oncol. 2017, 123, 203-208. [CrossRef] [PubMed]

64. Rades, D.; Bohlen, G.; Pluemer, A.; Veninga, T.; Hanssens, P.; Dunst, J.; Schild, S.E. Stereotactic radiosurgery alone versus resection plus whole-brain radiotherapy for 1 or 2 brain metastases in recursive partitioning analysis class 1 and 2 patients. Cancer 2007, 109, 2515-2521. [CrossRef] [PubMed]

65. Baliga, S.; Garg, M.K.; Fox, J.; Kalnicki, S.; Lasala, P.A.; Welch, M.R.; Tomé, W.A.; Ohri, N. Fractionated stereotactic radiation therapy for brain metastases: A systematic review with tumour control probability modelling. Br. J. Radiol. 2017, 90, 20160666. [CrossRef] [PubMed]

66. Hodi, F.S.; Chesney, J.; Pavlick, A.C.; Robert, C.; Grossmann, K.F.; McDermott, D.F.; Linette, G.P.; Meyer, N.; Giguere, J.K.; Agarwala, S.S.; et al. Combined nivolumab and ipilimumab versus ipilimumab alone in patients with advanced melanoma: 2-Year overall survival outcomes in a multicentre, randomised, controlled, phase 2 trial. Lancet Oncol. 2016, 17, 1558-1568. [CrossRef]

67. Larkin, J.; Chiarion-Sileni, V.; Gonzalez, R.; Grob, J.J.; Cowey, C.L.; Lao, C.D.; Schadendorf, D.; Dummer, R.; Smylie, M.; Rutkowski, P.; et al. Combined Nivolumab and Ipilimumab or Monotherapy in Untreated Melanoma. N. Engl. J. Med. 2015, 373, 1270-1271. [CrossRef] [PubMed]

68. Gettinger, S.; Rizvi, N.A.; Chow, L.Q.; Borghaei, H.; Brahmer, J.; Ready, N.; Gerber, D.E.; Shepherd, F.A.; Antonia, S.; Goldman, J.W.; et al. Nivolumab monotherapy for first-line treatment of advanced non-small-cell lung cancer. J. Clin. Oncol. 2016, 34, 2980-2987. [CrossRef] [PubMed] 
69. McDermott, D.F.; Drake, C.G.; Sznol, M.; Choueiri, T.K.; Powderly, J.D.; Smith, D.C.; Brahmer, J.R.; Carvajal, R.D.; Hammers, H.J.; Puzanov, I.; et al. Survival, durable response, and long-term safety in patients with previously treated advanced renal cell carcinoma receiving nivolumab. J. Clin. Oncol. 2015, 33, 2013-2020. [CrossRef] [PubMed]

70. Long, G.V.; Atkinson, V.; Lo, S.; Sandhu, S.; Guminski, A.D.; Brown, M.P.; Wilmott, J.S.; Edwards, J.; Gonzalez, M.; Scolyer, R.A.; et al. Combination nivolumab and ipilimumab or nivolumab alone in melanoma brain metastases: A multicentre randomised phase 2 study. Lancet Oncol. 2018, 19, 672-681. [CrossRef]

71. Goldberg, S.B.; Gettinger, S.N.; Mahajan, A.; Chiang, A.C.; Herbst, R.S.; Sznol, M.; Tsiouris, A.J.; Cohen, J.; Vortmeyer, A.; Jilaveanu, L.; et al. Pembrolizumab for patients with melanoma or non-small cell lung cancer and untreated brain metastases: Early analysis of a non-randomised, open-label, phase 2 trial. Lancet Oncol. 2016, 17, 976-983. [CrossRef]

72. Formenti, S.C.; Demaria, S. Combining radiotherapy and cancer immunotherapy: A paradigm shift. J. Natl. Cancer Inst. 2013, 105, 256-265. [CrossRef] [PubMed]

73. Shiao, S.L.; Coussens, L.M. The tumor-immune microenvironment and response to radiation therapy. J. Mammary Gland Biol. Neoplasia 2010, 15, 411-421. [CrossRef] [PubMed]

74. Shiao, S.L.; Ganesan, A.P.; Rugo, H.S.; Coussens, L.M. Immune microenvironments in solid tumors: New targets for therapy. Genes Dev. 2011, 25, 2559-2572. [CrossRef] [PubMed]

75. Deng, L.; Liang, H.; Burnette, B.; Beckett, M.T.; Darga, T.; Weichselbaum, R.R.; Fu, Y.X. Irradiation and anti-PD-L1 treatment synergistically promote antitumor immunity in mice. J. Clin. Invest. 2014, 124, 687-695. [CrossRef] [PubMed]

76. Berghoff, A.S.; Kiesel, B.; Widhalm, G.; Rajky, O.; Ricken, G.; Wöhrer, A.; Oberndorfer, F.; Dieckmann, K.; Filipits, M.; Marosi, C.; et al. IB-02 Role of tumor infiltrating lymphocytes and PDL1 expression in glioblastoma (GBM) and brain metastases (BM): Comparative analysis. Neuro Oncol. 2014, 16 (Suppl. 5), v107. [CrossRef]

77. Berghoff, A.S.; Ricken, G.; Widhalm, G.; Rajky, O.; Dieckmann, K.; Birner, P.; Bartsch, R.; Höller, C.; Preusser, M. Tumour-infiltrating lymphocytes and expression of programmed death ligand 1 (PD-L1) in melanoma brain metastases. Histopathology 2015, 66, 289-299. [CrossRef] [PubMed]

78. Berghoff, A.S.; Inan, C.; Ricken, G.; Widhalm, G.; Dieckmann, K.; Birner, P.; Oberndorfer, F.; Dome, B.; Bartsch, R.; Zielinski, C.; et al. 1324P Tumor-infiltrating lymphocytes (TILS) and PD-L1 expression in non-small cell lung cancer brain metastases (BM) and matched primary tumors (PT). Ann. Oncol. 2014, 25 (Suppl. 4), iv465-iv466. [CrossRef]

79. Colaco, R.J.; Martin, P.; Kluger, H.M.; Yu, J.B.; Chiang, V.L. Does immunotherapy increase the rate of radiation necrosis after radiosurgical treatment of brain metastases? J. Neurosurg. 2016, 125, 17-23. [CrossRef] [PubMed]

80. Williams, N.L.; Wuthrick, E.J.; Kim, H.; Palmer, J.D.; Garg, S.; Eldredge-Hindy, H.; Daskalakis, C.; Feeney, K.J.; Mastrangelo, M.J.; Kim, L.J.; et al. Phase 1 study of ipilimumab combined with whole brain radiation therapy or radiosurgery for melanoma patients with brain metastases. Int. J. Radiat. Oncol. Biol. Phys. 2017, 99, 22-30. [CrossRef] [PubMed]

81. Silk, A.W.; Bassetti, M.F.; West, B.T.; Tsien, C.I.; Lao, C.D. Ipilimumab and radiation therapy for melanoma brain metastases. Cancer Med. 2013, 2, 899-906. [CrossRef] [PubMed]

82. Patel, K.R.; Shoukat, S.; Oliver, D.E.; Chowdhary, M.; Rizzo, M.; Lawson, D.H.; Khosa, F.; Liu, Y.; Khan, M.K. Ipilimumab and stereotactic radiosurgery versus stereotactic radiosurgery alone for newly diagnosed melanoma brain metastases. Am. J. Clin. Oncol. 2017, 40, 444-450. [CrossRef] [PubMed]

83. Knisely, J.P.; Yu, J.B.; Flanigan, J.; Sznol, M.; Kluger, H.M.; Chiang, V.L. Radiosurgery for melanoma brain metastases in the ipilimumab era and the possibility of longer survival. J. Neurosurg. 2012, 117, 227-233. [CrossRef] [PubMed]

84. Mathew, M.; Tam, M.; Ott, P.A.; Pavlick, A.C.; Rush, S.C.; Donahue, B.R.; Golfinos, J.G.; Parker, E.C.; Huang, P.P.; Narayana, A. Ipilimumab in melanoma with limited brain metastases treated with stereotactic radiosurgery. Melanoma Res. 2013, 23, 191-195. [CrossRef] [PubMed]

85. Koller, K.M.; Mackley, H.B.; Liu, J.; Wagner, H.; Talamo, G.; Schell, T.D.; Pameijer, C.; Neves, R.I.; Anderson, B.; Kokolus, K.M.; et al. Improved survival and complete response rates in patients with advanced melanoma treated with concurrent ipilimumab and radiotherapy versus ipilimumab alone. Cancer Biol. Ther. 2017, 18, 36-42. [CrossRef] [PubMed] 
86. Kiess, A.P.; Wolchok, J.D.; Barker, C.A.; Postow, M.A.; Tabar, V.; Huse, J.T.; Chan, T.A.; Yamada, Y.; Beal, K. Stereotactic radiosurgery for melanoma brain metastases in patients receiving ipilimumab: Safety profile and efficacy of combined treatment. Int. J. Radiat. Oncol. Biol. Phys. 2015, 92, 368-375. [CrossRef] [PubMed]

87. An, Y.; Jiang, W.; Kim, B.Y.S.; Qian, J.M.; Tang, C.; Fang, P.; Logan, J.; D’Souza, N.M.; Haydu, L.E.; Wang, X.A.; et al. Stereotactic radiosurgery of early melanoma brain metastases after initiation of anti-CTLA-4 treatment is associated with improved intracranial control. Radiother. Oncol. 2017, 125, 80-88. [CrossRef] [PubMed]

88. Ahmed, K.A.; Stallworth, D.G.; Kim, Y.; Johnstone, P.A.; Harrison, L.B.; Caudell, J.J.; Yu, H.H.; Etame, A.B.; Weber, J.S.; Gibney, G.T. Clinical outcomes of melanoma brain metastases treated with stereotactic radiation and anti-PD-1 therapy. Ann. Oncol. 2016, 27, 434-441. [CrossRef] [PubMed]

89. Chen, L.; Douglass, J.; Kleinberg, L.; Ye, X.; Marciscano, A.E.; Forde, P.M.; Brahmer, J.; Lipson, E.; Sharfman, W.; Hammers, H.; et al. Concurrent immune checkpoint inhibitors and stereotactic radiosurgery for brain metastases in non-small cell lung cancer, melanoma, and renal cell carcinoma. Int. J. Radiat. Oncol. Biol. Phys. 2018, 100, 916-925. [CrossRef] [PubMed]

90. Nardin, C.; Mateus, C.; Texier, M.; Lanoy, E.; Hibat-Allah, S.; Ammari, S.; Robert, C.; Dhermain, F. Tolerance and outcomes of stereotactic radiosurgery combined with anti-programmed cell death-1 (pembrolizumab) for melanoma brain metastases. Melanoma Res. 2018, 28, 111-119. [CrossRef] [PubMed]

91. Anderson, E.S.; Postow, M.A.; Wolchok, J.D.; Young, R.J.; Ballangrud, Å.; Chan, T.A.; Yamada, Y.; Beal, K. Melanoma brain metastases treated with stereotactic radiosurgery and concurrent pembrolizumab display marked regression; efficacy and safety of combined treatment. J. Immunother. Cancer 2017, 5, 76. [CrossRef] [PubMed]

92. Anti-PD 1 Brain Collaboration + Radiotherapy: The ABC-X Study, 2018. ClinicalTrials.gov Web Site. Available online: https: / / clinicaltrials.gov / ct2/ show / NCT03340129 (accessed on 14 July 2018).

93. Lin, N.U.; Lee, E.Q.; Aoyama, H.; Barani, I.J.; Barboriak, D.P.; Baumert, B.G.; Bendszus, M.; Brown, P.D.; Camidge, D.R.; Chang, S.M.; et al. Response assessment criteria for brain metastases: Proposal from the RANO group. Lancet Oncol. 2015, 16, e270-e278. [CrossRef]

94. Patel, T.R.; Mchugh, B.J.; Bi, W.L.; Minja, F.J.; Knisely, J.P.; Chiang, V.L. A comprehensive review of MR imaging changes following radiosurgery to 500 brain metastases. Am. J. Neuroradiol. 2011, 32, 1885-1892. [CrossRef] [PubMed]

95. Hoefnagels, F.W.A.; Lagerwaard, F.J.; Sanchez, E.; Haasbeek, C.J.A.; Knol, D.L.; Slotman, B.J.; Vandertop, P.W. Radiological progression of cerebral metastases after radiosurgery: Assessment of perfusion MRI for differentiating between necrosis and recurrence. J. Neurol. 2009, 256, 878-887. [CrossRef] [PubMed]

96. Mitsuya, K.; Nakasu, Y.; Horiguchi, S.; Harada, H.; Nishimura, T.; Bando, E.; Okawa, H.; Furukawa, Y.; Hirai, T.; Endo, M. Perfusion weighted magnetic resonance imaging to distinguish the recurrence of metastatic brain tumors from radiation necrosis after stereotactic radiosurgery. J. Neurooncol. 2010, 99, 81-88. [CrossRef] [PubMed]

97. Huang, B.Y.; Kwock, L.; Castillo, M.; Smith, J.K. Association of choline levels and tumor perfusion in brain metastases assessed with proton MR spectroscopy and dynamic susceptibility contrast enhanced perfusion weighted MRI. Technol. Cancer Res. Treat. 2010, 9, 327-337. [CrossRef] [PubMed]

98. Chernov, M.F.; Hayashi, M.; Izawa, M.; Usukura, M.; Yoshida, S.; Ono, Y.; Muragaki, Y.; Kubo, O.; Hori, T.; Takakura, K. Multivoxel proton MRS for differentiation of radiation-induced necrosis and tumor recurrence after gamma knife radiosurgery for brain metastases. Brain Tumor Pathol. 2006, 23, 19-27. [CrossRef] [PubMed]

99. Stockham, A.L.; Suh, J.H.; Chao, S.T.; Barnett, G.H. Management of recurrent brain metastasis after radiosurgery. Prog. Neurol. Surg. 2012, 25, 273-286. [CrossRef] [PubMed]

100. Barajas, R.F.; Chang, J.S.; Sneed, P.K.; Segal, M.R.; McDermott, M.W.; Cha, S. Distinguishing recurrent intra-axial metastatic tumor from radiation necrosis following Gamma Knife radiosurgery using dynamic susceptibility-weighted contrast-enhanced perfusion MR imaging. Am. J. Neuroradiol. 2009, 30, 367-372. [CrossRef] [PubMed]

101. Zach, L.; Guez, D.; Last, D.; Daniels, D.; Grober, Y.; Nissim, O.; Hoffmann, C.; Nass, D.; Talianski, A.; Spiegelmann, R.; et al. Delayed contrast extravasation MRI: A new paradigm in neuro-oncology. Neuro Oncol. 2015, 17, 457-465. [CrossRef] [PubMed] 
102. Liu, H.; Andrews, D.W.; Evans, J.J.; Werner-Wasik, M.; Yu, Y.; Dicker, A.P.; Shi, W. Plan quality and treatment efficiency for radiosurgery to multiple brain metastases: Non-coplanar RapidArc vs. Gamma Knife. Front. Oncol. 2016, 6, 26. [CrossRef] [PubMed]

103. Ruggieri, R.; Naccarato, S.; Mazzola, R.; Ricchetti, F.; Corradini, S.; Fiorentino, A.; Alongi, F. Linac-based VMAT radiosurgery for multiple brain lesions: Comparison between a conventional multi-isocenter approach and a new dedicated mono-isocenter technique. Radiat. Oncol. 2018, 13, 38. [CrossRef] [PubMed]

104. Slosarek, K.; Bekman, B.; Wendykier, J.; Grzadziel, A.; Fogliata, A.; Cozzi, L. In silico assessment of the dosimetric quality of a novel, automated radiation treatment planning strategy for linac-based radiosurgery of multiple brain metastases and a comparison with robotic methods. Radiat. Oncol. 2018, 13, 41. [CrossRef] [PubMed]

105. Luo, G.; Neimat, J.S.; Cmelak, A.; Kirschner, A.N.; Attia, A.; Morales-Paliza, M.; Ding, G.X. Margin of error for a frameless image guided radiosurgery system: Direct confirmation based on posttreatment MRI scans. Pract. Radiat. Oncol. 2017, 7, e223-e231. [CrossRef] [PubMed]

106. Ezzell, G.A. The spatial accuracy of two frameless, linear accelerator-based systems for single-isocenter, multitarget cranial radiosurgery. J. Appl. Clin. Med. Phys. 2017, 18, 37-43. [CrossRef] [PubMed]

107. Babic, S.; Lee, Y.; Ruschin, M.; Lochray, F.; Lightstone, A.; Atenafu, E.; Phan, N.; Mainprize, T.; Tsao, M.; Soliman, H.; et al. To frame or not to frame? Cone-beam CT-based analysis of head immobilization devices specific to linac-based stereotactic radiosurgery and radiotherapy. J. Appl. Clin. Med. Phys. 2018, 19, 111-120. [CrossRef] [PubMed]

108. Nataf, F.; Schlienger, M.; Liu, Z.; Foulquier, J.N.; Gres, B.; Orthuon, A.; Vannetzel, J.M.; Escudier, B.; Meder, J.-F.; Roux, F.X.; et al. Radiosurgery with or without a 2-mm margin for 93 single brain metastases. Int. J. Radiat. Oncol. Biol. Phys. 2008, 70, 766-772. [CrossRef] [PubMed]

(C) 2018 by the authors. Licensee MDPI, Basel, Switzerland. This article is an open access article distributed under the terms and conditions of the Creative Commons Attribution (CC BY) license (http:/ / creativecommons.org/licenses/by/4.0/). 